НАУКОВИЙ ВІСНИК

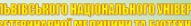

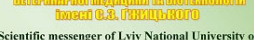

cientific messegger of Livi National University
Veterinary Medicine and Biotechnologies

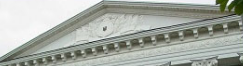

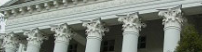

1

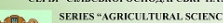

Tом 21 № 91

2019
Науковий вісник Дьвівського національного університету ветеринарної медицини та біотехнологій імені С.3. Гжицького. Серія: Сільськогосподарські науки

Scientific Messenger of Lviv National University of Veterinary Medicine and Biotechnologies. Series: Agricultural sciences

UDC 636.4.082.43

\title{
Feeding and meat qualities of young pigs of different origin and intensity of formation in early ontogenesis
}

\author{
V.I. Khalak ${ }^{1}$, B.V. Gutyj ${ }^{2}$, O.I. Stadnits'ka ${ }^{3}$ \\ ${ }^{1}$ State Institution Institute of grain crops of NAAS, Dnipro, Ukraine \\ ${ }^{2}$ Stepan Gzhytskyi National University of Veterinary Medicine and Biotechnologies Lviv, Ukraine \\ ${ }^{3}$ Institute of Agriculture of the Carpathian region of NAAS, Obroshino, Ukraine
}

Article info

Received 02.09.2019

Received in revised form 01.10 .2019

Accepted 02.10.2019

State Institution Institute of grain crops of NAAS, V. Vernadsky Str. 14, Dnipro, 49027, Ukraine. Tel: $+38-067-892-44-04$

E-mail:v16kh91@gmail.com

Stepan Gzhytskyi National University of Veterinary Medicine and Biotechnologies Lviv, Pekarska Str., 50, Lviv, 79010, Ukraine.

Institute of Agriculture of the Carpathian region of the National Academy of Agrarian Sciences of Ukraine Grushevskogo Str. 5, Obroshino, Pustomytovsky District, Lviv Region, 81115, Ukraine.
Khalak, V.I., Gutyj, B.V., \& Stadnits'ka, O.I. (2019). Feeding and meat qualities of young pigs of different origin and intensity of formation in early ontogenesis. Scientific Messenger of Lviv National University of Veterinary Medicine and Biotechnologies. Series: Agricultural sciences, 21(91), 10-15. doi: $10.32718 /$ nvlvet-a9102

The results of studies of fattening and meat qualities of young pigs of different origin and intensity of formation in early ontogenesis are presented. The economic efficiency of the results of the studies is calculated. The study was conducted under the conditions of pedigree reproducer for breeding pigs of the large white breed of LTD "Druzhba-Kaznacheevka" of Dnipropetrovsk region. The object of study was young pigs of English and Hungarian origin, as well animals of varying intensity of formation in early ontogenesis. Estimation of young pigs by absolute and integrated indicators of fattening and meat qualities was carried out taking into account the following quantitative characteristics: average daily weight gain for the period of control fattening, $\mathrm{kg}$, age of reaching live weight of $100 \mathrm{~kg}$, days, thickness of the lard at the level of 6-7 thorax, mm, length of cooled carcass, $\mathrm{cm}$, length of bacon half carcass, $\mathrm{cm}$, index "intensity of formation" $(\Delta t)$, selection index (SI) and "T-factor". The economic efficiency of the results of the research was calculated according to the indicator "average daily increase of live weight during the period of control fattening, $\mathrm{kg}^{\prime}$. The analysis of the results of the research shows that the young pigs of the large white breed of the control herd by the age of reaching the live weight of $100 \mathrm{~kg}$ were outweighed by the minimum requirements of the Instruction for pig testing by $9.78 \%$, by the thickness of the lard at the level of 6-7 thoracic vertebrae - by $30.33 \%$ and by length of the cooled carcass - by $3.52 \%$. Taking into account the class of origin and index "intensity of formation, points" $(\Delta t)$, the difference between the groups by age of reaching live weight of $100 \mathrm{~kg}$, the thickness of the pelvis at the level of 6-7 thoracic vertebrae and the length of the cooled carcass ranges from 2.24 to $8.03 \%$. It was found that in terms of the main indicators of fattening and meat quality, the young pigs of the large white breed of Hungarian breeding are more consolidated $\left(K_{1}=\right.$ $0.085-0.344, K_{2}=0.086-0.338$ ). The maximum increment of additional production (average daily weight gain during the control fattening period, $\mathrm{kg}$ ) was obtained from young pigs of large white breed of English origin (2.39\%) and animals with index $\Delta t$ at the level of 0.619-0.748 points $(1.38 \%)$. To evaluate the animals of the main herd (brood boars, sows) according to the fattening and meat characteristics of their offspring, we suggest the use of SI and T-factor breeding indices.

Key words: young pigs, breed, fattening and meat quality, index, phenotype consolidation, variability, economic efficiency.

\section{Відгодівельні та м'ясні якості молодняку свиней різного походження та інтенсивності формування у ранньому онтогенезі}

\author{
В.I. Халак ${ }^{1}$, Б.В. Гутий르, О.І. Стадницька ${ }^{3}$ \\ 'Державна установа “Інститут зернових культур НААН України”, м Дніпро, Україна
}


${ }^{2}$ Львівський національний університет ветеринарної медицини та біотехнологій імені С.3. Гжсицького, м. Львів, Україна

${ }^{3}$ Інститут сільського господарства Карпатського регіону НААН Украӥни, с. Оброшино, Пустомитівський район, Львівська область, Украӥна

Наведено результати досліджень відгодівельних та м'ясних якостей молодняку свиней різного походження та інтенсивності формування у ранньому онтогенезі, розраховано економічну ефективність результатів досліджень. Дослідження проведено в умовах племінного репродуктора з розведення свиней великої білої породи СТОВ “Дружба-Казначеївка” Дніпропетровської області. Об'єктом дослідження був молодняк свиней зазначеної породи англійського та угорського походження, а також тварини різної інтенсивності формування у ранньому онтогенезі. Оиінку молодняку свиней за абсолютними та інтегрованими показниками відгодівельних та м'ясних якостей проводили з урахуванням таких кількісних ознак: середньодобовий приріст живої маси за період контрольної відгодівлі, кг, вік досягнення живої маси 100 кг, діб, товщина шпику на рівні 6-7 грудних хребців, мм, довжина охолодженої туші, см, довжина беконної половини туші, см, індекс “інтенсивність формування” ( $\Delta t)$, селекційний індекс (СИ) та “Тфактор”. Економічну ефективність результатів досліджень розраховували за показником “середньодобовий приріст живої маси за період контрольної відгодівлі, кг”. Аналіз результатів досліджень свідчить, щзо молодняк свиней великої білої породи підконтрольного стада за віком досягнення живої маси 100 кг переважав мінімальні вимоги Інструкиї з бонітування свиней на 9,78\%, за товщиною шиику на рівні 6-7 грудних хребиів - на 30,33\% та за довжиною охолодженої туші - на 3,52\%. 3 урахуванням класу

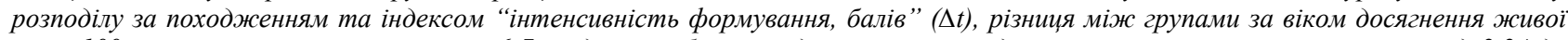
маси 100 кг, товщчною шпику на рівні 6-7 грудних хребиів та довжиною охолодженої туші коливається у межах від 2,24 до 8,03\%. Встановлено, щзо за основними показниками відгодівельних та м'ясних якостей більш консолідованими є молодняк свиней великої білої породи угорської селекиії $\left(K_{1}=0,085-0,344, K_{2}=0,086-0,338\right)$. Максимальну надбавку додаткової продукиї (середньодобовий приріст живої маси за період контрольної відгодівлі, кг) одержано від молодняку свиней великої білої породи англійського походження (2,39\%) та тварин з індексом $\Delta t$ на рівні 0,619-0,748 балів (1,38\%). Для оиінки тварин основного стада (кнуриплідники, свиноматки) за відгодівельними та м'ясними якостями їхнього потомства пропонуємо використовувати селекційний індекси СИ та “Т-фактор”.

Ключові слова: молодняк свиней, порода, відгодівельні та м'ясні якості, індекс, фенотипна консолідація, мінливість, економічна ефективність.

\section{Вступ}

Дослідженнями вітчизняних та зарубіжних вчених встановлено, що на економічну ефективність галузі свинарства поряд 3 показниками відтворювальної здатності свиноматок та кнурів-плідників (Lugovyi, 2005; Tserenyuk et al., 2010; Hunchak et al., 2018; Kramarenko et al., 2018; 2019) суттєво впливає рівень відгодівельних та м'ясних якостей молодняку свиней (Balatskyi, 2015; Berezovskyi et al., 2016; Nechmilov, 2018; Nechmilov \& Povod, 2018). Для поліпшення зазначених груп ознак в селекційних програмах передбачається використання високопродуктивних тварин вітчизняної селекції, а також зарубіжного походження (Grishina, \& Fesenko, 2015). Важливим при цьому залишається пошук та використання ефективних методів оцінки племінної цінності свиней у ранньому онтогенезі (Vashchenko et al., 2015; Tsibenko et al., 2018).

Таким чином, метою роботи було дослідити відгодівельні та м'ясні якості молодняку свиней різного походження та інтенсивності формування у ранньому онтогенезі, розрахувати економічну ефективність результатів досліджень.

\section{Матеріал і методи досліджень}

Дослідження проведено в умовах племінного репродуктора з розведення свиней великої білої породи CTOB “Дружба-Казначеївка” Дніпропетровської області, лабораторії тваринництва ДУ Інститут зернових культур НААН та приватного підприємства “М'ясна фабрики “Джаз”.

Оцінку молодняку свиней за відгодівельними i м'ясними якостями проводили з урахуванням наступних абсолютних показників: середньодобовий приріст живої маси за період контрольної відгодівлі, кг, вік досягнення живої маси 100 кг, діб, товщина шпику на рівні 6-7 грудних хребців, мм, довжина охолодженої туші, см, довжина беконної половини туші, см.

Індекси “інтенсивність формування" $(\Delta \mathrm{t})(1)$, СИ (2) та "Т-фактор" (Hazei \& Kline, 1952) (3) розраховували за формулами:

$$
\Delta t=\frac{W_{4}-W_{2}}{0,5 \times\left(W_{4}+W_{2}\right)}-\frac{W_{6}-W_{4}}{0,5 \times\left(W_{6}+W_{4}\right)},
$$

де: $\mathrm{W}_{2}, \mathrm{~W}_{4}, \mathrm{~W}_{6}-$ жива маса молодняку свиней у відповідні вікові періоди - 2, 4, і 6 - місячному віці, кг (Svechin, 1985; Kovalenko et al., 2008);

$$
\text { СИ }=100-\left(1,13 \times \mathrm{x}_{1}+5,13 \times \mathrm{x}_{4}\right) \div 3,6
$$

де: СИ - селекційний індекс, балів, $x_{l}$ - вік досягнення живої маси 100 кг, діб, $x_{4}$ - товщина шпику, мм (Bazhov \& Komlatsky, 1989).

$$
T_{2}=\frac{\text { Товщзина шпику, мм }}{\text { Довжина охолодженної туші, см }}
$$

Коефіцієнт фенотипної консолідації ознак молодняку свиней різного походження розраховували за методикою Ю.П. Полупана:

$$
\begin{aligned}
& K_{1}=1-\frac{\sigma_{2}}{\sigma_{3}} \\
& K_{2}=1-\frac{C v_{2}}{C v_{3}}
\end{aligned}
$$

де: $\sigma$ г і cv г - середньоквадратичне відхилення та коефіцієнт мінливості оцінюваної групи тварин за конкретною ознакою, б 3 і cv 3 - ті самі показники генеральної сукупності (Polupan, 1996).

Економічну ефективність проведених досліджень розраховували за формулою:

$$
E=Ц \times \frac{C \times \Pi}{100} \times Л \times K
$$


де: Е - вартість додаткової продукції, грн.; Ц - закупівельна ціна одиниці продукції, відповідно цін, які діють в Україні, грн.; С - середня продуктивність тварин; П - середня надбавка основної продукції (\%), яка виражена у відсотках на 1 голову при застосуванні нового і поліпшеного селекційного досягнення порівняно 3 продуктивністю тварин базового використання; Л - постійний коефіцієнт зменшення результату, який пов'язаний з додатковими витратами на прибуткову продукцію $(0,75)$; К - чисельність поголів'я сільськогосподарських тварин нового або поліпшеного селекційного досягнення, голів. Економічну ефективність проведених досліджень розраховували за ознакою “середньодобовий приріст живої маси за період контрольної відгодівлі, кг”.

Біометричну обробку одержаних результатів досліджень проведено за методикою (Lakyn, 1990).

\section{Результати та їх обговорення}

Дослідження показали, що молодняк свиней підконтрольного стада характеризується достатньо висо- кими показниками відгодівельних і м'ясних якостей. Так, вік досягнення живої маси 100 кг становить $172,7 \pm 1,11$ доби $(\mathrm{Cv}=4,12 \%)$, середньодобовий приріст живої маси за період контрольної відгодівлі $0,571 \pm 0,0036$ кг $(\mathrm{Cv}=4,12 \%)$, товщина шпику на рівні 6-7 грудних хребців - 21,41 $\pm 0,294 \mathrm{мм}(\mathrm{Cv}=$ $8,79 \%$ ), довжина охолодженої туші - 96,4 $\pm 0,59$ см $(\mathrm{Cv}=2,22 \%)$, довжина беконної половини туші $80,8 \pm 0,89$ см $(\mathrm{Cv}=4,00 \%)$. Селекційний індекс (CИ) та “Т-фактор" коливаються у межах від 8,67 до 22,48 та 0,186 до 0,252 балів.

Аналіз зазначених груп ознак у тварин різних походження показав, що молодняк свиней I (велика біла англійського походження) групи переважали ровесників II (велика біла угорського походження) за віком досягнення живої маси 100 кг на 6,4 доби $(\mathrm{td}=3,00$; $\mathrm{P}<0,01)$, середньодобовим приростом живої маси за період контрольної відгодівлі - на 0,022 кг (td = 3,14; $\mathrm{P}<0,01)$, товщиною шпику на рівні 6-7 грудних хребців - на 0,7 мм $(\mathrm{td}=1,06 ; \mathrm{P}>0,05)$ (табл. 1$)$.

\section{Таблиця 1}

Відгодівельні та м’ясні якості молодняку свиней різного походження

\begin{tabular}{|c|c|c|c|}
\hline \multirow{4}{*}{ Показники, одиниці виміру } & \multirow{4}{*}{$\begin{array}{c}\text { Біометричні } \\
\text { показники }\end{array}$} & \multicolumn{2}{|c|}{ Походження } \\
\hline & & $\begin{array}{c}\text { Велика біла англійського } \\
\text { походження }\end{array}$ & $\begin{array}{c}\text { Велика біла угорського } \\
\text { походження }\end{array}$ \\
\hline & & \multicolumn{2}{|c|}{ Група } \\
\hline & & I & II \\
\hline \multirow{4}{*}{$\begin{array}{l}\text { Середньодобовий приріст живої } \\
\text { маси за період контрольної відго- } \\
\text { дівлі, кг }\end{array}$} & $\mathrm{n}$ & 14 & 27 \\
\hline & $\overline{\mathrm{X}} \pm S \bar{x}$ & $0,585 \pm 0,0058$ & $0,563 \pm 0,0040$ \\
\hline & $\sigma$ & 0,021 & 0,021 \\
\hline & $\mathrm{Cv}, \%$ & 3,70 & 3,77 \\
\hline \multirow{3}{*}{$\begin{array}{l}\text { Вік досягнення живої маси } 100 \text { кг, } \\
\text { діб }\end{array}$} & $\overline{\bar{X}} \pm S \bar{x}$ & $168,5 \pm 1,731$ & $174,9 \pm 1,256$ \\
\hline & $\sigma$ & 6,480 & 6,528 \\
\hline & $\mathrm{Cv}, \%$ & 3,84 & 3,73 \\
\hline \multirow{3}{*}{$\begin{array}{l}\text { Товщина шпику на рівні } \\
\text { 6-7 грудних хребців, мм }\end{array}$} & $\overline{\mathrm{X}} \pm S \bar{x}$ & $20,9 \pm 0,59$ & $21,6 \pm 0,32$ \\
\hline & $\sigma$ & 2,234 & 1,664 \\
\hline & $\mathrm{Cv}, \%$ & 10,67 & 7,68 \\
\hline \multirow{4}{*}{ СИ - селекційний індекс, балів } & $\lim$ & $10,35-21,17$ & $8,67-22,48$ \\
\hline & $\overline{\mathrm{X}} \pm S \bar{x}$ & $17,28 \pm 0,957$ & $14,21 \pm 0,611$ \\
\hline & $\sigma$ & 3,581 & 3,179 \\
\hline & $\mathrm{Cv}, \%$ & 20,71 & 22,35 \\
\hline \multirow{4}{*}{ довжина охолодженої туші, см } & $\mathrm{n}$ & 5 & 8 \\
\hline & $\overline{\mathrm{X}} \pm S \bar{x}$ & $97,8 \pm 0,84$ & $95,6 \pm 0,49$ \\
\hline & $\sigma$ & 2,588 & 1,407 \\
\hline & $\mathrm{Cv}, \%$ & 2,64 & 1,47 \\
\hline \multirow{3}{*}{$\begin{array}{l}\text { довжина беконної половини туші, } \\
\text { см }\end{array}$} & $\overline{\mathrm{X}} \pm S \bar{x}$ & $82,4 \pm 0,72$ & $79,8 \pm 0,91$ \\
\hline & $\sigma$ & 3,847 & 2,587 \\
\hline & $\mathrm{Cv}, \%$ & 4,67 & 3,23 \\
\hline \multirow{4}{*}{ Т-фактор, балів } & $\lim$ & $0,186-0,247$ & $0,206-0,252$ \\
\hline & $\overline{\mathrm{X}} \pm S \bar{x}$ & $2,204 \pm 0,0109$ & $0,230 \pm 0,0070$ \\
\hline & $\sigma$ & 0,024 & 0,020 \\
\hline & $\mathrm{Cv}, \%$ & 11,92 & 8,69 \\
\hline
\end{tabular}

Різниця між групами за селекційним індексом (СИ) склала 3,07 бала (td = 5,99; $\mathrm{P}<0,001)$, довжиною охолодженої туші $-2,2 \mathrm{~cm}(\mathrm{td}=2,29$; $\mathrm{P}<0,05)$, довжина беконної половини туші $-2,6$ см $(\mathrm{td}=2,36$; $\mathrm{P}<0,05)$. Молодняк свиней великої білої породи англійського походження характеризувався меншою товщиною шпику на рівні 6-7 грудних хребців, більшою довжиною туші і як наслідок меншим індексом “Т-фактор" (на 0,026 бала, td = 2,16; Р < 0,05).

Коефіцієнт мінливості абсолютних та інтегрованих показників відгодівельних та м'ясних якостей молодняку свиней великої білої породи англійського 
та угорського походження коливався у межах від 1,47 до $22,35 \%$.

Результати досліджень відгодівельних і м’ясних якостей молодняку свиней великої білої породи 3 урахуванням індексу “інтенсивності формування, балів” ( $\Delta \mathrm{t})$ наведено в таблицях 2.

\section{Таблиця 2}

Відгодівельні та м’ясні якості молодняку свиней великої білої різної інтенсивності формування у ранньому онтогенезі

\begin{tabular}{|c|c|c|c|c|}
\hline \multirow{4}{*}{ Показники, одиниці виміру } & \multirow{4}{*}{$\begin{array}{l}\text { Біометричні } \\
\text { показники }\end{array}$} & \multicolumn{3}{|c|}{ Група } \\
\hline & & I & II & III \\
\hline & & \multicolumn{3}{|c|}{ Індекс “інтенсивності формування” $(\Delta t)$, балів } \\
\hline & & $0,896-1,024$ & $0,754-0,875$ & $0,619-0,748$ \\
\hline \multirow{4}{*}{$\begin{array}{l}\text { Середньодобовий приріст живої } \\
\text { маси за період контрольної від- } \\
\text { годівлі, кг }\end{array}$} & $\mathrm{n}$ & 9 & 22 & 10 \\
\hline & $\overline{\mathrm{X}} \pm S \bar{x}$ & $0,564 \pm 0,0041$ & $0,571 \pm 0,0046$ & $0,579 \pm 0,0053$ \\
\hline & $\sigma$ & 0,024 & 0,021 & 0,026 \\
\hline & $\mathrm{Cv}, \%$ & 4,31 & 3,85 & 4,54 \\
\hline \multirow{3}{*}{$\begin{array}{l}\text { Вік досягнення живої маси } 100 \\
\text { кг, діб }\end{array}$} & $\overline{\mathrm{X}} \pm S \bar{x}$ & $175,9 \pm 1,53$ & $172,8 \pm 1,41$ & $169,4 \pm 1,47$ \\
\hline & $\sigma$ & 7,590 & 6,629 & 7,814 \\
\hline & $\mathrm{Cv}, \%$ & 4,31 & 3,83 & 4,61 \\
\hline \multirow{3}{*}{$\begin{array}{l}\text { Товщина шпику на рівні } \\
\text { 6-7 грудних хребців, мм }\end{array}$} & $\overline{\bar{X}} \pm S \bar{x}$ & $22,4 \pm 0,44$ & $21,3 \pm 0,41$ & $20,6 \pm 0,58$ \\
\hline & $\sigma$ & 1,333 & 1,965 & 1,837 \\
\hline & $\mathrm{Cv}, \%$ & 5,94 & 9,19 & 8,92 \\
\hline \multirow{4}{*}{ СИ - селекційний індекс, балів } & $\lim$ & $10,35-19,37$ & $8,67-22,48$ & $13,18-22,03$ \\
\hline & $\overline{\mathrm{X}} \pm S \bar{x}$ & $13,10 \pm 0,981$ & $15,28 \pm 0,758$ & $17,17 \pm 1,067$ \\
\hline & $\sigma$ & 2,943 & 3,559 & 3,374 \\
\hline & $\mathrm{Cv}, \%$ & 22,46 & 23,28 & 19,64 \\
\hline \multirow{3}{*}{ довжина охолодженої туші, см } & $\overline{\mathrm{X}} \pm S \bar{x}$ & $95,2 \pm 0,58$ & $96,8 \pm 0,58$ & $98,0 \pm 1,12$ \\
\hline & $\sigma$ & 1,303 & 1,303 & 3,605 \\
\hline & $\mathrm{Cv}, \%$ & 1,36 & 1,34 & 3,67 \\
\hline \multirow{3}{*}{$\begin{array}{l}\text { довжина беконної половини } \\
\text { туші, см. }\end{array}$} & $\overline{\mathrm{X}} \pm S \bar{x}$ & $79,0 \pm 1,09$ & $81,0 \pm 1,26$ & $83,7 \pm 1,58$ \\
\hline & $\sigma$ & 2,44 & 2,828 & 3,785 \\
\hline & $\mathrm{Cv}, \%$ & 3,10 & 3,49 & 4,52 \\
\hline \multirow{4}{*}{ Т-фактор, балів } & $\lim$ & $0,206-0,252$ & $0,193-0,247$ & $0,186-0,252$ \\
\hline & $\bar{X} \pm S \bar{x}$ & $0,231 \pm 0,0094$ & $0,214 \pm 0,0096$ & $0,211 \pm 0,0207$ \\
\hline & $\sigma$ & 0,021 & 0,021 & 0,035 \\
\hline & $\mathrm{Cv}, \%$ & 9,14 & 10,02 & 16,94 \\
\hline
\end{tabular}

Встановлено, що молодняк свиней III групи $(\Delta \mathrm{t}=$ 0,619-0,748) переважав ровесників II $(\Delta \mathrm{t}=0,754$ $0,875)$ та I груп $(\Delta t=0,896-1,024)$ за віком досягнення живої маси 100 кг на $3,4(\mathrm{td}=1,67 ;$ Р > 0,05) і 6,5 доби $(\mathrm{td}=3,06 ; \mathrm{td}=2,16 ; \mathrm{P}<0,01)$, середньодобовим приростом живої маси за період контрольної відгодівлі на $0,009(\mathrm{td}=1,28 ; \mathrm{P}>0,05)$ і 0,015 кг $(\mathrm{td}=2,50$; $\mathrm{P}<0,05)$. Різниця між групами за товщиною шпику на рівні 6-7 грудних хребців склала 0,7 (td $=0,82$; $\mathrm{P}>0,05)$ i 1,8 мм $(\mathrm{td}=2,50 ; \mathrm{P}<0,05)$, селекційним індексом (СИ) - 1,89 (td $=1,45 ; \mathrm{P}>0,05)$ i 4,07 бала $(\mathrm{td}=2,82 ; \mathrm{P}<0,05)$, довжиною охолодженої туші $-1,2$ $(\mathrm{td}=0,96 ; \mathrm{P}>0,05)$ і $2,8 \mathrm{~cm}(\mathrm{td}=2,24 ; \mathrm{P}<0,05)$, довжина беконної половини туші $-2,7$ (td $=1,34$; $\mathrm{P}>0,05)$ i 4,7 cм $(\mathrm{td}=2,46 ; \mathrm{P}<0,05)$. Мінімальне значення індексу “Т-фактор" виявлено у тварин III групи $(\Delta \mathrm{t}=0,619-0,748)-0,211 \pm 0,0207$ балів.

Коефіцієнт мінливості абсолютних та інтегрованих показників відгодівельних та м'ясних якостей молодняку свиней великої білої породи з урахуванням класу розподілу за індексом “інтенсивності формування, балів" $(\Delta \mathrm{t})$ коливався у межах від 1,34 до $23,28 \%$.

Консолідація селекційної групи тварин - процес досягнення певної стабільності генотипової та фенотипової подібності за селекційними ознаками серед структурних одиниць породи, стада, яка реалізується через відносне звуження генотипної i фенотипної мінливості, закріплення їх на бажаному рівні прояву за відповідної взаємодії “генотип-середовище”, що гарантовано забезпечує високу спадкову стійкість їхньої передачі тваринами своєму потомству (Polupan, 2001).

Результати досліджень фенотипної консолідації відгодівельні та м'ясні якості молодняку свиней великої білої породи різного походження наведено в таблиці 3. 
Таблиця 3

Коефіцієнт фенотипної консолідації відгодівельні та м’ясні якості молодняку свиней великої білої породи різного походження

\begin{tabular}{|c|c|c|c|}
\hline \multirow[b]{2}{*}{ Показники, одиниці виміру } & \multirow[b]{2}{*}{$\begin{array}{l}\text { Коефіцієнт фенотипної } \\
\text { консолідації }\end{array}$} & \multicolumn{2}{|c|}{ Група } \\
\hline & & $\begin{array}{c}\text { велика біла англійського } \\
\text { походження }\end{array}$ & $\begin{array}{c}\text { велика біла угорсь- } \\
\text { кого походження }\end{array}$ \\
\hline \multirow{2}{*}{$\begin{array}{l}\text { Середньодобовий приріст живої маси за } \\
\text { період контрольної відгодівлі, кг }\end{array}$} & $\mathrm{K}_{1}$ & 0,079 & 0,098 \\
\hline & $\mathrm{K}_{2}$ & 0,101 & 0,086 \\
\hline \multirow{2}{*}{ Вік досягнення живої маси 100 кг, діб } & $\mathrm{K}_{1}$ & 0,091 & 0,085 \\
\hline & $\mathrm{K}_{2}$ & 0,926 & 0,096 \\
\hline \multirow{2}{*}{$\begin{array}{l}\text { Товщина шпику на рівні 6-7 грудних } \\
\text { хребців, мм }\end{array}$} & $\mathrm{K}_{1}$ & $-0,186$ & 0,117 \\
\hline & $\mathrm{K}_{2}$ & $-0,214$ & 0,127 \\
\hline \multirow{2}{*}{ Довжина охолодженої туші, см } & $\mathrm{K}_{1}$ & $-0,207$ & 0,344 \\
\hline & $\mathrm{K}_{2}$ & $-0,190$ & 0,338 \\
\hline \multirow{2}{*}{ Довжина беконної половини туші, см } & $\mathrm{K}_{1}$ & $-0,189$ & 0,200 \\
\hline & $\mathrm{K}_{2}$ & $-0,167$ & 0,191 \\
\hline
\end{tabular}

Встановлено, що у тварин великої білої породи англійського та угорського походження коефіцієнт фенотипної консолідації "К" $\mathrm{K}_{1}$ " коливався у межах від -0,207 до 0,344, “К2”- від -0,214 до 0,926.

За основними показниками відгодівельних і м'ясних якостей молодняку свиней більш консолідованими є тварин угорського походження.

Таблиця 4

Економічна ефективність результатів досліджень
Розрахунки економічної ефективності результатів досліджень показали, що максимальну прибавку продукції одержано від молодняку свиней I (клас розподілу з урахуванням походження тварин) та III груп (класу розподілу за індексом "інтенсивності формування, балів" $(\Delta \mathrm{t})$, а саме $+2,39-+1,38 \%$ відповідно (табл. 4).

\begin{tabular}{cccc}
\hline Група & $\mathrm{n}$ & $\begin{array}{c}\text { Середньодобовий приріст живої маси за } \\
\text { період контрольної відгодівлі, кг }\end{array}$ & Надбавка продукції, \% \\
\hline Загальна вибірка & 41 & $0,571 \pm 0,0036$ & - \\
\hline \multicolumn{4}{c}{ клас розподілу з урахуванням походження тварин } \\
\hline I & 27 & $0,563 \pm 0,0040$ & $-1,40$ \\
\hline I & 14 & $0,585 \pm 0,0058$ & $+2,39$ \\
\hline II & 9 & класу розподілу за індексом «інтенсивності формування, балів» $(\Delta t)$ \\
III & 22 & $0,564 \pm 0,0041$ & $-1,22$ \\
\hline
\end{tabular}

\section{Висновки}

1. Молодняк свиней великої білої породи підконтрольного стада характеризується достатньо високими показниками відгодівельних та м'ясних якостей. Так, за віком досягнення живої маси 100 кг вони переважають мінімальні вимоги Інструкції з бонітування свиней на 9,78\%, за товщиною шпику на рівні 67 грудних хребців - на 30,33\% та за довжиною охолодженої туші - на 3,52\%.

2. 3 урахуванням класу розподілу за походженням та індексом “інтенсивність формування, балів" $(\Delta t)$, різниця між групами за віком досягнення живої маси 100 кг, товщиною шпику на рівні 6-7 грудних хребців та довжиною охолодженої туші коливається у межах від 2,24 до 8,03\%. Встановлено, що за основними показниками відгодівельних та м'ясних якостей більш консолідованими є молодняк свиней великої білої породи угорської селекції.

3. Максимальну прибавку додаткової продукції (середньодобовий приріст живої маси за період контрольної відгодівлі, кг) одержано від молодняку свиней великої білої породи англійського походження
$(2,39 \%)$ та тварин з індексом $\Delta \mathrm{t}$ на рівні $0,619-0,748$ балів $(1,38 \%)$.

4. Для оцінки тварин основного стада (кнуриплідники, свиноматки) за відгодівельними та м'ясними якостями їх потомства пропонуємо використовувати селекційний індекси СИ та “Т-фактор”.

\section{References}

Balatskyi, V.M. (2015). Association of growth hormone releasing factor gene with quality of pigs of large white breed of Ukrainian breeding. Swine breeding, 67, 107-112 (in Ukrainian).

Bazhov, G.M., \& Komlatsky, V.I. (1989). Biotechnology of intensive pig breeding. M.: Rosagropromizdat (in Russian).

Berezovskyi, M.D., Onishchenko, A.A., \& Vashchenko, P.A. (2016). Evaluation of fattening and meat characteristics of pigs of large white breed of factory type Bogachansky. Pig breeding: an interagency thematic scientific collection of the Institute of Pig Breeding and APV NAAS. Poltava, 68, 40-47 (in Ukrainian). 
Grishina, L.P., \& Fesenko, A.G. (2015). Efficiency of use of specialized pig type for crossbreeding and hybridization. Bulletin of agrarian science of the Black Sea, 2(84), 40-47. https://visnyk.mnau.edu.ua/en/ tag/Гришина-Л-П/ (in Ukrainian).

Hazei, L.N., \& Kline, E.A. (1952). Mechanical Meassurement of Fatness and Carcass Value in Live Hogs. J. Anim., 11(2), 313-318. doi: $10.2527 /$ jas 1952.112313x.

Hunchak, R.V., Sedilo, H.M., Kystsiv, V.O., Gutyj, B.V., \& Hunchak, V.M. (2018). Total liquid maintenance and correlation of their classes in the sow's colostrum and milk at different levels of aquacart of Iodine in their rations. Ukrainian Journal of Ecology, 8(1), 644 648. doi: 10.15421/2017 261.

Kovalenko, V.P., Nezhlukchenko, T.I., \& Plotkin, S.Ya. (2008). Modern methods of estimation and prediction of patterns of ontogeny of animals and birds. Bulletin of agrarian science, 2, 40-45 (in Ukrainian).

Kramarenko, S.S., Lugovoy, S.I., Lykhach, A.V., Kramarenko, A.S., Lykhach, V.Ya., \& Slobodianyk, A.A. (2019). Effect of genetic and non-genetic factors on the reproduction traits in Ukrainian Meat sows. Scientific Messenger of Lviv National University of Veterinary Medicine and Biotechnologies. Series: Agricultural sciences, 21(90), 3-8. doi: 10.32718/nvlvet-a9001 (in Ukrainian).

Kramarenko, S.S., Lugovoy, S.I., Lykhach, A.V., Kramarenko, A.S., Lykhach, V.Ya. (2018). A comparative study of the reproductive traits and clustering analysis among different pig breeds. Scientific Messenger of Lviv National University of Veterinary Medicine and Biotechnologies, 20(84), 2126. doi: 10.15421/nvlvet8404 (in Ukrainian).

Lakyn, H.F. (1990). Byometryia: uchebnoe posobye [dlia byol. spets. vuzov]. Moskow, Vysshaia shkola (in
Russian).

Lugovyi, S.I. (2005). Reproductive ability of sows of a large white breed of English breeding. Agrarian Bulletin of the Black Sea, 31, 44-45 (in Ukrainian).

Nechmilov, V.M. (2018). The influence of the factor of the method of hybrid pigs feeding while growing on the meat quality. Scientific Messenger of Lviv National University of Veterinary Medicine and Biotechnologies, 20(89), 56-60. doi: 10.32718/ nvlvet8910 (in Ukrainian).

Nechmilov, V.M., \& Povod, M.G. (2018). Feedback performance of pigs at different growing times and use of dry and liquid types of feeding. Bulletin of Sumy NAU, 7(35), 122-134 (in Ukrainian).

Polupan, Yu.P. (1996). Assessment of the degree of phenotypic consolidation of genealogical groups of animals. Zootechnics, 10, 13-15 (in Ukrainian).

Polupan, Yu.P. (2001). Consolidation problems of different animal breeding groups. Bulletin of agrarian science, 12, 41-46 (in Ukrainian).

Svechin, Yu.K. (1985). Predicting early animal productivity. Herald s.h. Sciences, 4, 103-108 (in Russian).

Tserenyuk, O.M., Khvatov, A.I., \& Strizhak, T.A. (2010). Evaluation of the performance of pigs' maternal productivity indices. Collection of scientific works of Vinnitsa NAU, 3(42), 73-77 (in Ukrainian).

Tsibenko, V.G., Vaschenko, P.A., \& Saenko, A.M. (2018). The latest breeding and genetic methods in breeding work with the Myrhorod pig breed. Poltava, 71, 70-78 (in Ukrainian).

Vashchenko, P.A., Balatsky, V.N., \& Pochnernyaev, K.F. (2015). Using the BLUP model with the inclusion of DNA-markers for assessing pigs. Zootechnical science of Belarus. Collection of scientific papers: genetics, breeding, breeding, reproduction biotechnology and reproduction, 50(1), 43-50 (in Ukrainian). 